\title{
VOORZICHTIG MET DEN BODEM VAN SURINAME!
}

\author{
DOOR
}

C. H. DE GOEJE

Enkele jaren geleden was ik te Rio de Janeiro voor besprekingen over de grensafbakening Suriname-Brazilië.

Daar viel het mij plotseling op: De granietbergen met hun vaak grillige vormen in en om Rio de Janeiro en bij het naburige Therezópolis, dat is de Toemoekhoemak!

Ginds, in Suriname, is het door het eentonig geboomte niet opvallend van schoonheid; in Rio, met de diepblauwe of zilverspiegelende zee en de witte huizen tusschen de bergen, is het een der mooiste plekjes van de aarde. Maar overigens is het hetzelfde.

En wat, naar men mij te Rio mededeelde, wel is voorgekomen, dat een plek ontboscht werd en daarna op de steen niets meer wilde groeien, dat zou ook in Suriname kunnen gebeuren.

Welk een omvang een bodemverwoesting kan aannemen, kan men dezer dagen zien in Noord-Amerika. Uitgestrekte gebieden zijn daar in korten tijd tot woestijnen geworden, of weinig beter, doordien de menschen er roekeloos de vegetatie vernield hebben, waarna wind en water de vruchtbare aarde hebben weggevoerd. Men rekent, dat het groote inspanning zal kosten en dat het een langdurig proces zal zijn, om dat weer in orde te krijgen, terwijl er gedeelten zijn, die misschien nooit meer goed zullen worden.

Sommigen vermoeden, dat aan iets dergelijks, zij het al niet in zoo snel tempo, ook het onvruchtbaar worden van streken bij de Westkust van Zuid-Amerika is te wijten, en dat veel woestijngebied in de Oude Wereld op die wijze ontstaan is.

Het grootste gedeelte van Suriname heeft een granietbodem (nader in R. IJzerman's Outline of the Geology and Petrology of Surinam, Utrecht 1931). Afgezien van stukken savane in het brongebied van de Sipaliwini (boven-Corantijn), is het alles met oerwoud begroeid. Er is behoorlijk water; de inboorlingen hebben er bruikbare grond voor het verbouwen van hun voe- 
dingsgewassen; aan hout en andere boschprodukten en aan dieren is er geen gebrek.

Maar, dat de aarde niet veel houvast heeft aan den steenen ondergrond, vermoedelijk doordien deze geen spleten en scheurtjes heeft, waarin water en plantenwortels kunnen doordringen, dat is wel te zien op de boven het oerwoud uitstekende toppen, zooals Teboe aan de Tapanahoni, enz., welker schedel vrijwel volkomen kaal is, naakte, bijna onverweerde steen. Er zijn ook hier en daar kale steenplekken die niet boven het woud uitsteken; misschien een gevolg van brand?

Behoudens op die enkele plekken en in de rivierbeddingen is overal de steen met aarde bedekt en als een Indiaan of Boschneger een stuk woud velt en er een kostgrond aanlegt en deze na eenige jaren weder verlaat, dan groeit zoo'n kleine plek in het onmetelijke oerwoud vanzelf weder dicht.

Dat zou echter wel eens anders kunnen worden, als men grootere plekken van woud ontblootte. Te oordeelen naar wat in Noord-Amerika geschiedt, is er bovendien het gevaar, dat als eenmaal de wind en het water vat krijgen op den bodem, het voortvreet en ten slotte zelfs het klimaat zich kan wijzigen.

Het tegenwoordig bedrijf der Indianen en Boschnegers levert, voor zoover ik kan oordeelen, nog geen gevaar op, en een plaatselijk onderzoek, hoezeer ook wenschelijk, lijkt voor het oogenblik nog niet volstrekt noodig. Maar het ware een punt om van nu af op te letten bij elke uitgifte van land of vestiging in het binnenland; een oogje op de Boschnegers, naarmate deze hun leefwijze gaan veranderen, is ook niet overbodig en evenmin eenige oplettendheid, wat er bij de buren nabij onze grens voorvalt.

Het Rijk als geheel zou wel eens groote behoefte kunnen krijgen aan de uitgestrekte terreinen in tropisch land, die thans nog ongebruikt liggen. Daarom is waakzaamheid ten deze plicht.

Bezit het Bestuur van Suriname de noodige wettelijke bevoegdheden om te kunnen voorkomen en indien noodig onverwijld te kunnen ingrijpen? En is er een ambtelijk orgaan, dat op deze dingen te letten heeft? Zoo neen, dan ware hierin thans te voorzien.

Het zij mij veroorloofd hierop eerbiedig de aandacht te vestigen van het Bestuur van Suriname en het Opperbestuur; en ook van de Vertegenwoordigende Lichamen en de Pers. 